\title{
Characteristics of viral pneumonia in the COVID-19 era: an update
}

\author{
P. Pagliano ${ }^{1} \cdot$ C. Sellitto ${ }^{2}$ V. Conti ${ }^{2} \cdot$ T. Ascione $^{3} \cdot$ Silvano Esposito $^{1}$ (B)
}

Received: 26 January 2021 / Accepted: 6 March 2021 / Published online: 29 March 2021

(c) Springer-Verlag GmbH Germany, part of Springer Nature 2021

\begin{abstract}
Influenza virus, rhinovirus, and adenovirus frequently cause viral pneumonia, an important cause of morbidity and mortality especially in the extreme ages of life. During the last two decades, three outbreaks of coronavirus-associated pneumonia, namely Severe Acute Respiratory Syndrome, Middle-East Respiratory Syndrome, and the ongoing Coronavirus Infectious Disease-2019 (COVID-19) were reported. The rate of diagnosis of viral pneumonia is increasingly approaching 60\% among children identified as having community-acquired pneumonia (CAP). Clinical presentation ranges from mild to severe pneumonitis complicated by respiratory failure in severe cases. The most vulnerable patients, the elderly and those living with cancer, report a relevant mortality rate. No clinical characteristics can be useful to conclusively distinguish the different etiology of viral pneumonia. However, accessory symptoms, such as anosmia or ageusia together with respiratory symptoms suggest COVID-19. An etiologic-based treatment of viral pneumonia is possible in a small percentage of cases only. Neuraminidase inhibitors have been proven to reduce the need for ventilatory support and mortality rate while only a few data support the large-scale use of other antivirals. A low-middle dose of dexamethasone and heparin seems to be effective in COVID-19 patients, but data regarding their possible efficacy in viral pneumonia caused by other viruses are conflicting. In conclusion, viral pneumonia is a relevant cause of CAP, whose interest is increasing due to the current COVID-19 outbreak. To set up a therapeutic approach is difficult because of the low number of active molecules and the conflicting data bearing supportive treatments such as steroids.
\end{abstract}

Keywords Viral pneumonia $\cdot$ SARS-CoV-2 $\cdot$ Remdesivir $\cdot$ Neuraminidase inhibitor $\cdot$ Steroids $\cdot$ Heparin

\section{Background}

Viral pneumonia is a complex disease because the diagnosis can be difficult and frequently based on the exclusion of bacterial etiology, and its treatment can be ineffective due to the low number of molecules active against viruses commonly involved [1].

In recent times, the availability of PCR-based Multiplex tests, which enable the simultaneous identification of

Silvano Esposito

silvanoesposito@libero.it

1 Department of Medicine, Surgery and Dentistry, "Scuola Medica Salernitana", Unit of Infectious Diseases, University of Salerno, Baronissi, Italy

2 Department of Medicine, Surgery and Dentistry, "Scuola Medica Salernitana”, Unit of Pharmacology, University of Salerno, Baronissi, Italy

3 Department of Medicine, Service of Infectious Diseases, Cardarelli Hospital, Naples, Italy a wide number of viruses, is contributing to the increase of the number of viral pneumonia diagnosis, improving the awareness of viruses as causative agents for respiratory mild and severe infections $[2,3]$. As a general concept, viruses belonging to adenovirus, meta-pneumovirus, para-influenza virus, respiratory syncytial virus (RSV), and influenza A and $B$ viruses families cause the majority of cases of viral pneumonia, which generally report mild symptoms and low mortality. Instead, Herpes Virus (HSV), Cytomegalovirus (CMV) and Epstein-Barr Virus (EBV) are responsible for severe and life-threatening cases among immunocompromised patients [4].

Coronaviruses have been commonly identified as the etiologic agents of the 'Common cold' (HCoV 229E and OC43), but during the last decades they have been associated with 3 novel severe diseases, all caused by a zoonotic spillover namely Severe Acute Respiratory Syndrome (SARS), Middle-East Respiratory Syndrome (MERS), and the ongoing coronavirus infectious disease-19 (COVID-19) outbreak $[5,6]$. 
Treatment of severe viral pneumonia is mostly supportive. Antiviral medications, such as acyclovir, ribavirin, palivizumab, oseltamivir, zanamivir, amantadine and rimantadine, are available and effective in selected cases only [7]. Polyclonal intravenous immunoglobulin-based immunotherapy has been used, but current data do not allow their large-scale employment [8]. Management of patients requiring intensive care unit (ICU) admission for severe viral pneumonia is based on mechanical ventilation using lower tidal volumes and correction of septic shock, besides appropriate antiviral treatment, when feasible.

Here, we aim to summarize the current knowledge on epidemiology, etiology and treatment of viral pneumonia by means of a narrative review, highlighting similarities and differences between those caused by SARS-CoV-2 and those caused by previously known viral agents.

\section{Epidemiology}

Viral pneumonia is predominant among very young children ( $<5$ years) and adults aging $>50$ years. The most common isolates in adults are adenoviruses, coronaviruses, human metapneumovirus, human rhinoviruses, influenza viruses, parainfluenza viruses and respiratory syncytial virus, but an exact picture of epidemiologic findings is difficult to establish due to not optimal surveillance systems in all countries, a high rate of coinfections, and the lack of a precise definition of viral pneumonia [9].

Large studies suggest that the etiology of pneumonia is more frequently viral than bacterial. The "EPIC" (Etiology of Pneumonia in the Community) study, a prospective multicenter study based on the analysis of a large population in the United States, demonstrated that the prevalence and the incidence of pneumonia vary by age. Among 2222 children included in the study a pathogen was detected in 1802 (81\%) children; $66 \%$ of them (1472 in total) reported a viral infection; otherwise, bacteria were found in $175(8 \%)$ cases and viral and bacterial coinfection was found in 155 cases (7\%). The most common viruses were RSV (28\%), human rhinoviruses $(27 \%)$, human metapneumovirus (13\%), adenoviruses (11\%), parainfluenza 1 to 3 viruses (7\%), influenza A and B viruses (7\%) and coronaviruses (5\%); indeed, RSV, adenoviruses and human metapneumovirus were commonly detected in children younger than 5 years old. Among 2259 adults enrolled in the same study, a pathogen was detected in 853 (38\%) patients only; 530 (23\%) had viral pneumonia, while bacterial pneumonia was diagnosed in 247 (11\%); coinfections were found in 59 cases (3\%), and fungal as well as a mycobacterial pathogen in 17 (1\%) cases. The most common viruses were human rhinoviruses (9\%), influenza A and B viruses (6\%), human metapneumovirus (4\%), RSV (3\%), parainfluenza 1 to 3 viruses (2\%), coronaviruses (2\%) and adenoviruses (1\%) [10].
A large systematic review on the etiology of CAP in European adults identified 28 studies reporting quantitative data on viral pneumonia prevalence [11]. Based on a meta-analysis of studies investigating patients diagnosed as having CAP, the cumulative incidence of viral pneumonia was estimated as $22 \%$. Studies included in the systematic review had a large variability in the percentage of viral isolates and those using polymerase chain reaction (PCR)based methods for diagnosis had the highest number of viral isolates. Interestingly, studies reporting a low risk of bias highlighted a percentage of viral isolates approaching $30 \%$. Pooled analysis revealed that influenza virus A and B were the most common viruses identified accounting for $9 \%$ of the cases, and that rhinovirus, coronavirus and parainfluenza virus were identified in a percentage of cases between 2 and $7 \%$ [11]. Based on a retrospective study including patients with respiratory tract infection diagnosed by a multiplex PCR test, RSV can be detected during the influenza season in parallel to influenza virus infection in an approximate 1:7 relation [12].

In approaching viral pneumonia diagnosis, PCR-based diagnostic tests are more sensitive than standard methods, but viral genomic material identified by these tests can derive from recent viral infections, which are not responsible for the ongoing pulmonary infection. A study investigating over 300 patients suffering from CAP, whose etiologic diagnosis was based on both standard culture and multiplexbased analysis of respiratory specimens, identified viral pathogens in $30 \%$ of respiratory specimens, but in many cases, viruses and bacteria were simultaneously detected and a precise diagnosis of viral pneumonia could be obtained in $5.6 \%$ of the cases only [13].

Viral pneumonia has an important impact on ageing populations and in those living with cancer. A Swiss study enrolling patients ageing $>65$ years with suspected CAP screened for viral pathogens by PCR analysis of nasopharyngeal swabs demonstrated the presence of a viral genome in $31 \%$ of the cases. Rhinovirus and Influenza A/B viruses were those most identified and evidence of both bacterial and viral infection was detected in about $10 \%$ of the cases [14]. Instead, a study including a large population of patients with viral pneumonia highlighted that an active cancer was a strong independent predictor of 30-day mortality [15].

Currently, the ongoing outbreak of COVID-19 is reporting high mortality and morbidity with over 80 million cases diagnosed in every part of the world. COVID-19 has rapid diffusion and reports a high mortality rate in elderly and immunocompromised patients. As for other etiologies of viral pneumonia, bacterial super infections were reported especially in severe cases [16, 17]. COVID-19 spreads rapidly when CAP viruses are at their annual peak and preliminary studies suggest that SARS-CoV-2 could have a competitive effect on other respiratory viruses circulation [18]. 


\section{Clinical presentation}

Clinical presentation of viral pneumonia ranges from mild pneumonia with fever, cough, and shortness of breath to severe pneumonia with sepsis and respiratory distress. Symptoms severity is related to the individual local and systemic immune response. Non-productive cough along with dyspnea and pleuritic chest pain are the most common symptoms of viral pneumonia. Fever, chills, fatigue, malaise, pleuritic chest pain, and anorexia are frequently reported. In severe cases, signs of physical examination also include tachypnea, an increase in breathing rate, and abnormal loud breath sounds. Hypoxemia is commonly reported due to the impairment of alveolar gas exchange [19].

The initial presentation of sepsis secondary to viral pneumonia may be based on new-onset or worsening hypotension, altered mental status and other signs of organ dysfunction, such as renal dysfunction, liver dysfunction, or thrombocytopenia and should be differentiated by bacterial superinfection. Sometimes, ageing patients, immunocompromised patients, or those living with chronic obstructive pulmonary disease can have a less specific presentation with rapidly worsening clinical conditions [20]. In some cases, the activation of the inflammatory response caused by a viral infection can trigger a pro-coagulative status thereby increasing the risk of cerebrovascular events in apparently low-risk patients [21].

\section{Influenza}

Approximately one-third of patients recurring to hospital care because of Influenza virus-associated has pneumonia, which can be directly related to Influenza virus or caused by bacterial superinfection [22]. A study investigating 579 hospitalized adult patients with influenza virus infection, highlighted that those presenting with acute respiratory failure (OR 4.525; 95\% CI 2.964-6.907) and those presenting with productive cough (OR 8.173; 95\% CI 3.674-18.182) had the higher risk to be affected by pneumonia [23]. In a small percentage of cases, pneumonia can lead to severe hypoxemic respiratory failure, evolving towards acute respiratory distress syndrome (ARDS), with shock and acute renal failure. Pneumonia caused by Influenza A (H1N1) can have a severe clinical impact, as demonstrated by a study comparing each other patients with a respiratory infection admitted in hospital during 4 years. In this study, patients affected by Influenza A (H1N1) were younger at admission and reported a higher percentage of pulmonary complications, ICU admission, and mortality rate. Despite these differences in terms of outcome, no difference between Influenza A (H1N1) and Influenza $\mathrm{A} / \mathrm{H} 3 \mathrm{~N} 2$ can be reported looking for symptoms at admission [24].

\section{Parainfluenza virus}

Patients suffering from Parainfluenza virus infection report mild and rapidly resolving upper respiratory symptoms and only a few cases evolve towards severe clinical conditions. Parainfluenza virus 3 reports the highest rate of complications. A Chinese study investigating 178 patients with an upper respiratory specimen positive for Parainfluenza viruses revealed that most cases were in pediatric age and one-third were co-infected with other respiratory pathogens. The main symptoms reported were cough (94\%) and fever $(55 \%)$ and the proportion of patients with pneumonia was $16 \%$, but no difference in terms of disease presentation was reported [25]. A systematic review on patients affected by hematologic malignancy or receiving hemopoietic cell transplantation with parainfluenza virus infection highlighted a $37 \%$ incidence of pneumonia and an associated mortality rate equal to $27 \%$, irrespective of the underlying condition [26].

\section{Respiratory syncytial virus}

Respiratory syncytial virus (RSV) is responsible for recurrent respiratory infections in infants (bronchiolitis during the first year of life) and mild pneumonia in immunocompetent adults. A study considering elderly and high-risk patients hospitalized after the onset of RSV-associated illness, demonstrated a $20 \%$ incidence of pneumonia [27]. Patients with RSV report a longer time from the beginning of symptoms to hospital admission when compared to other cases with an Influenza-like illness (ILI), and bacterial super infections in $12 \%$ of cases [28]. Another study investigating the clinical characteristics of patients affected with an ILI, demonstrated that those reporting RSV infection had a diagnosis of pneumonia in over $40 \%$ of cases and had a high rate of respiratory failure. Anti-cancer or immunosuppressive treatments were significant risks for RSV pneumonia [29].

\section{Adenovirus}

Adenovirus affects the upper respiratory tract, but it can even cause pneumonia whose clinical findings are like other viral pneumonia. In a multicenter surveillance study investigating 969 patients with pneumonia in China, 5\% had pneumonia sustained by adenovirus. These cases had a median age remarkably lower than the ones reported for other patients with an ILI. Those infected by adenovirus serotype 55 were older and had a major probability to be affected by an underlying disease. More than $50 \%$ of patients with adenovirus 
pneumonia required hospitalization, $29 \%$ needed oxygen therapy and two patients needed mechanical ventilation [30]. Similar findings were reported in a meta-analysis of 228 case-report of patients with adenovirus disease [31]. After an outbreak of adenovirus infection occurred at the Korean military training center in 2015,191 patients with pneumonia were investigated: five patients had severe pneumonia and one died. High prolonged fever, nasal congestion and sore throat were common symptoms. Febrile leukopenia $(62.7 \%)$ and thrombocytopenia (41\%) were frequent, while only $12 \%$ presented with leukocytosis [32].

\section{Rhinovirus}

Rhinovirus affects the upper respiratory tract in adults and children causing an infection characterized by sneezing and secretions, sore throat, and low-grade fever in many cases. Lower respiratory tract infection and acute respiratory distress syndrome (ARDS) are reported in a few cases among elderly and immunocompromised patients. A study comparing the characteristics of patients with severe rhinovirus -pneumonia to those with Influenza virus, reported an immunocompromised status or immunosuppressive drug administration. It is relevant to state that in this study patients admitted to ICU with viral pneumonia sustained by rhinovirus or influenza virus reported a mortality approaching $50 \%[33,34]$.

\section{Cytomegalovirus}

CMV pneumonia has a very low frequency among immunocompetent patients. A recent literature review reports 17 cases only of viral pneumonia sustained by CMV in immunocompetent, most of these patients presented with fever, flu-like illness and shortness of breath and cough. Jaundice and abdominal pain were the main extrapulmonary symptoms reported. Interestingly, 2 women were in the peripartum period [35].

CMV interstitial pneumonitis reports the highest frequency in hematopoietic stem cell transplant (HSCT) recipients and in solid organ transplant recipients, where it is associated with an increase in terms of mortality [36]. A study investigating the complications of patients undergoing bone marrow transplantation identified 16 cases of CMV pneumonia. In these cases, fever and cough were the main symptoms, hypoxia was reported in about $60 \%$ and dyspnea in 53\%. A $31 \%$ mortality rate was reported in these cases. Similar findings were reported in another study on patients receiving allogeneic BMT transplantation. Both studies found a relationship between CMV pneumonia and an increase of procedure-related mortality rate $[37,38]$.

\section{Other viral etiologies of viral pneumonia}

Besides CMV, other viruses belonging to the Herpesvirus family can cause pneumonia. A study evaluating 102 adult cases with severe VZV pneumonia demonstrated that over half of the cases were immunocompromised patients. Clinical findings included fever and dyspnea in virtually all cases, the cough was reported in $44 \%$, hemoptysis in $10 \%$. Immunocompromised patients had a more severe course of the disease, as demonstrated by the higher rate of cases requiring mechanical ventilation. Hospital mortality was $24 \%$ [39]. Herpes Simplex Virus (HSV) pneumonia is rather uncommon and diagnosed mainly in immunocompromised. Its diagnosis is difficult due to HSV shedding can be reported in $2-3 \%$ of individuals in the general population making its presence in low tract respiratory specimens difficult to interpreter. A study on immunocompromised patients using strict parameters including cytopathologic examination demonstrated the presence of HSV-DNA in $42 \%$ of low respiratory tract specimens, but only $24 \%$ fulfilled the criteria for HSV pneumonia. Mortality approached to $25 \%$ in these cases. Another study evaluating patients with viral pneumonia highlight that HSV1-DNA was detected in $32 \%$ of the cases, but no difference in terms of mortality could be detected after treatment with acyclovir, making rather questionable the role of HSV in these cases [40, 41].

\section{COVID-19}

COVID-19 has clinical characteristics, which were reported rarely in the cases of pneumonia sustained by other viral agents. While general symptoms of pulmonary involvement are quite indistinguishable from other etiology of viral pneumonia, many aspects deserve particular attention. A large systematic review shows that, besides common accessory symptoms (fever, cough, and dyspnea), loss of gustatory and olfactory functions, gastrointestinal symptoms, and headache can be reported in some cases. These accessory symptoms should be considered in suspecting COVID-19 in patients presenting with worsening respiratory symptoms to provide supportive care and limit intra-hospital diffusion. Severe cases evolve towards an ARDS and require ventilatory support. In some cases, signs of neurologic involvement can be reported as late complications of COVID-19. About 50\% of the patients have relevant comorbidities and bacterial coinfections can be reported in about $20 \%$ of the cases at the time of Intensive Care Unit admission. Clinical manifestations in children are usually mild, because of a less pronounced inflammatory response. Patients surviving to COVID-19 can report alteration in lung function that can benefit of a rehabilitative treatment [42-46]. 


\section{Management of viral pneumonia}

Viral pneumonia has few opportunities in terms of therapy and the standard of care is supportive treatment in most cases. Most common antiviral agents have limited availability in many areas and the use of drugs such as steroids or heparin is not supported by large controlled studies.

\section{Antivirals}

In the suspicion of pneumonia caused by the Influenza virus, drug therapy should begin before laboratory confirmation. Oseltamivir, zanamivir and peramivir reduce morbidity and mortality in Influenza virus A and B infection, acting as neuraminidase inhibitors and affecting viral propagation [47, 48]. Early antiviral treatment is preferred and zanamivir is recommended as first- line therapy because of the potential resistance of influenza A (H1N1) virus to oseltamivir [49, 50]. CDC guidelines recommend therapy with oseltamivir for influenza virus pneumonia and with peramivir when a deficit in oseltamivir oral absorption is suspected.

Neuraminidase inhibitors investigations regard mainly patients with uncomplicated Influenza A infection. PRIDE study analyzing a large sample of patients with Influenza pneumonia demonstrated that early treatment ( $\leq 2$ days) with neuraminidase inhibitors did not reduce the risk of pneumonia onset compared with untreated subjects. Instead, in patients with Influenza pneumonia, early neuraminidase inhibitor treatment compared to later treatment was associated with significantly lower rates of ventilatory support and death [51]. Amantadine and rimantadine have been proposed for the treatment of Influenza because they act on viral membrane protein M2, which is implicated in the fusion of the viral envelope with the cytoplasmic membrane and can block viral RNA replication. The quality of studies on Amantadine and rimantadine activity is low and their use is limited by adverse drug reactions and rapid development of resistance. No data are currently available in their role on Influenza pneumonia treatment [52].

Ribavirin has been largely employed in the treatment of infants with bronchiolitis, but only a few data support its use in the treatment of RSV pneumonia. Ribavirin can be administered by mouth, intravenously, or aerosolized and can be difficult to administer to mechanically ventilated patients because aerosols can deposit in the ventilator delivery system. Concerns about the risk of hemolytic anemia and teratogenicity limit the use of ribavirin. Experience on ribavirin treatment of adults with pneumonia sustained by RSV is limited mainly to immunocompromised patients. In these cases, treatment efficacy is influenced by the immune status of patients and the benefit derived by ribavirin treatment is poor, also when specific immunoglobulins are administered [53, 54].

Valganciclovir or ganciclovir are routinely administered to patients receiving organs from CMV seropositive donors or to patients with HIV at high risk of CMV disease [55, 56]. When valganciclovir and ganciclovir are administered to patients with CMV pneumonia, a considerable benefit can be observed, as reported in patients with CMV pneumonia complicating bone-marrow transplantation [57]. The efficacy of these drugs can be well demonstrated by a study enrolling 100 immunocompromised patients who developed ARDS after CMV pneumonia that had an improvement in terms of mortality rate after ganciclovir treatment [58].

In an observational study, one hundred-two patients suffering from VZV pneumonia admitted to an intensive care unit received acyclovir $10 \mathrm{mg} / \mathrm{kg}$ every $8 \mathrm{~h}$ during an average of 11 days. Hospital mortality was $24 \%$, regardless of acyclovir administration, and patients receiving steroids experienced a longer duration of mechanical ventilation and prolonged hospitalization [39]. Treatment of rhinovirus pneumonia is primarily supportive. In this setting, several antiviral drugs such as pleconaril, ruprintrivir, or repurposing drugs such as itraconazole have been evaluated, but none have achieved solid results in terms of efficacy [59].

Although several drugs with antiviral activity have been proposed for the treatment of COVID-19 patients, no study can support their routine use. Remdesivir, lopinavir, aminoquinolines and other drugs with proven antiviral activity against other viruses have been investigated, but no efficacy was demonstrated by large trials as either treatment or prophylaxis [60-62].

Pharmacological options for Influenza Virus Pneumonia, along with other viral pneumonia, are summarized in Table 1.

\section{Steroids}

The use of steroids in patients with viral pneumonia can be proposed to reduce the deleterious effects of immune response triggered by viruses, but their efficacy is long to be demonstrated. Current IDSA/ATS guidelines on community-acquired pneumonia do not support steroids use. A meta-analysis including ten studies evaluating patients with influenza pneumonia associated the use of steroids with a higher risk of death, a longer length of stay in the intensive care unit, and a higher rate of secondary infections, only risk of mechanical ventilation duration was not affected [63]. Furthermore, a cohort study on 241 patients affected by ARDS after influenza virus infection highlights that early treatment with steroids can be associated with an increase in hospital mortality rate $(43.5 \%$ vs. $19.2 \%, p<0.001)$ [64]. 
Table 1 Main antiviral treatments active in patients with viral pneumonia

\begin{tabular}{|c|c|c|c|}
\hline Main indication for the treatment & Medication & Dosage & Notes \\
\hline \multirow{3}{*}{$\begin{array}{l}\text { Uncomplicated Influenza } \\
\text { Influenza pneumonia }\end{array}$} & Oseltamivir & Oral $75 \mathrm{mg}$ twice daily for 5 days & Dose adjustment for $\mathrm{CrCl}<50 \mathrm{ml} /$ \\
\hline & Peramivir & $\begin{array}{l}\text { Intravenous } 600 \mathrm{mg} \text { single dose (5 days for } \\
\text { complicated Influenza) }\end{array}$ & $\begin{array}{l}\text { Efficacy is not established for severe } \\
\text { Influenza A and for Influenza B }\end{array}$ \\
\hline & Zanamivir & $\begin{array}{l}\text { Intravenous } 300 \mathrm{mg} \text { daily for } 5-10 \text { days } \\
10 \mathrm{mg} \text { inhaled } \mathrm{q} 12 \mathrm{hr} \text { for } 5-10 \text { days }\end{array}$ & $\begin{array}{l}\text { Bronchospasm can occur in patients with } \\
\text { asthma }\end{array}$ \\
\hline RSV infection in immunocompromised & Ribavirin & $\begin{array}{l}\text { Aerosolized } 2 \text { g over } 2 \mathrm{~h} \text { every } 8 \mathrm{~h} \\
\text { Systemic oral or intravenous (dosage vari- } \\
\text { able) }\end{array}$ & $\begin{array}{l}\text { Inhalatory formulation can deposit in the } \\
\text { delivery system if ventilated } \\
\text { Hemolytic anemia } \\
\text { Teratogenic }\end{array}$ \\
\hline Severe adenovirus infection & Cidofovir & $\begin{array}{l}\text { Intravenous } 5 \mathrm{mg} / \mathrm{kg} / \text { weekly, until symp- } \\
\text { toms resolve }\end{array}$ & $\begin{array}{l}\text { Very limited data } \\
\text { Nephrotoxicity }\end{array}$ \\
\hline Varicella pneumonitis & Acyclovir & $\begin{array}{l}\text { Intravenous } 10 \mathrm{mg} / \mathrm{kg} / \mathrm{dose} \text { every } 8 \mathrm{~h} \text { for at } \\
\text { least } 7 \text { days }\end{array}$ & Nephrotoxicity \\
\hline CMV pneumonia & Ganciclovir & $\begin{array}{l}\text { Intravenous } 5 \mathrm{mg} / \mathrm{kg} / \mathrm{dose} \text { every } 12 \mathrm{~h} \text { for at } \\
\text { least } 2 \text { weeks }\end{array}$ & $\begin{array}{l}\text { Hematologic toxicity } \\
\text { Nephrotoxicity (dose adjustment for } \\
\mathrm{CrCl}<70)\end{array}$ \\
\hline COVID-19 & Remdesivir & $\begin{array}{l}\text { Day } 1 \text { loading dose: } 200 \mathrm{mg} \text { IV over } \\
30-120 \mathrm{~min} \\
\text { Day 2-6: } 100 \mathrm{mg} \text { IV q Day }\end{array}$ & Hepatotoxicity \\
\hline
\end{tabular}

$C M V$ cytomegalovirus, $\mathrm{CrCl}$ creatinine clearance, $\mathrm{HCW}$ healthcare workers, $H M P V$ human metapneumovirus, $P I V$ parainfluenza viruses, $R S V$ respiratory syncytial virus

Despite all these investigations arguing against steroid use in patients with viral pneumonia, there is a growing body of evidence on the effectiveness of low-dose steroids in selected cases. In a case- control study on 2141 influenza A (H1N1) patients with viral pneumonia, the subgroup of patients with $\mathrm{PaO}_{2} / \mathrm{FiO}_{2}<300 \mathrm{mmHg}$ receiving low/moderate doses of steroids had a significant reduction in both 30-day and 60-day mortality [65]. Further data favoring steroids administration are reported in patients with COVID19. RECOVERY trial highlights a favorable outcome for patients needing oxygen supplementation receiving $6 \mathrm{mg}$ of dexamethasone over a 10-day period [66]. A meta-analysis of 7 studies on the effects of steroids administration to COVID-19 patients admitted in ICU, intubated, or receiving high-flow oxygen, reported an advantage in terms of mortality reduction for the studies considering dexamethasone administration, but not for those considering hydrocortisone or methyl-prednisolone administration. No change in terms of mortality was reported after the use of high doses of steroids or in those receiving vasoactive drugs at enrollment

Table 2 Studies assessing the effectiveness of steroids in patients with viral pneumonia

\begin{tabular}{|c|c|c|c|c|c|}
\hline Article & Study type & Therapy & Etiology & Patients (n) & Effects \\
\hline 63 & Meta-analysis & $\begin{array}{l}\text { CS } \\
\text { vs } \\
\text { No CS treatment }\end{array}$ & Influenza virus & 4916 & $\begin{array}{l}\text { Higher mortality (OR } 1.98,95 \% \text { CI } \\
1.62-2.43, p<0.00001) \text { in CS group }\end{array}$ \\
\hline 64 & Retrospective cohort study & $\begin{array}{l}\text { Early CS treatment } \\
\text { vs } \\
\text { Non early CS treatment }\end{array}$ & Influenza virus & 241 & Higher hospital mortality rate in CS group \\
\hline 65 & Case control study & $\begin{array}{l}\text { Low-to-moderate dose } \\
\text { vs } \\
\text { High-dose CS }\end{array}$ & Influenza A (H1N1) & 2141 & $\begin{array}{l}\text { Reduced 30-day and 60-day mortality in } \\
\text { patients receiving low-to-moderate-CS } \\
\text { dose with } \mathrm{PaO}_{2} / \mathrm{FiO}_{2}<300 \mathrm{~mm} \mathrm{Hg}\end{array}$ \\
\hline 66 & Randomized controlled trial & $\begin{array}{l}\text { Dexamethasone } \\
\text { vs } \\
\text { Standard of care }\end{array}$ & COVID-19 & 6425 & $\begin{array}{l}\text { Reduced 28-day mortality rate in the } \\
\text { dexamethasone group receiving ventila- } \\
\text { tory support }\end{array}$ \\
\hline 67 & Meta-analysis & $\begin{array}{l}\text { CS } \\
\text { vs } \\
\text { Standard of care }\end{array}$ & COVID-19 & 1703 & $\begin{array}{l}\text { Advantage after treatment with dexameth- } \\
\text { asone ( } 6 \mathrm{mg} \text { daily) }\end{array}$ \\
\hline
\end{tabular}

CS: corticosteroid, ARDS: Acute Respiratory Distress Syndrome, aHR: adjusted Hazard Ratio, IMV: invasive mechanical ventilation 
Table 3 Efficacy of NIV in patients with viral pneumonia

\begin{tabular}{|c|c|c|c|c|c|}
\hline Reference & Study type & NIV & Etiology & Patients (n) & Effects \\
\hline 72 & $\begin{array}{l}\text { Retrospective analysis of a } \\
\text { registry }\end{array}$ & $\begin{array}{l}\text { Conventional invasive ventila- } \\
\text { tion } \\
\text { vs } \\
\text { Non-invasive ventilation }\end{array}$ & Influenza $\mathrm{A}(\mathrm{H} 1 \mathrm{~N} 1)$ & 685 & $\begin{array}{l}\text { No difference in respect to NIV } \\
\text { use } \\
\text { Lower APACHE II score, lower } \\
\text { SOFA score, fewer than two } \\
\text { chest X-ray quadrant opacities, } \\
\text { hemodynamic stability and } \\
\text { absence of renal failure or } \\
\text { MODS were associated with } \\
\text { NIV success }\end{array}$ \\
\hline 73 & $\begin{array}{l}\text { Retrospective single-centre } \\
\text { study }\end{array}$ & $\begin{array}{l}\text { Conventional invasive ventila- } \\
\text { tion } \\
\text { vs } \\
\text { Non-invasive ventilation }\end{array}$ & Influenza $\mathrm{A}(\mathrm{H} 1 \mathrm{~N} 1)$ & 32 & $\begin{array}{l}\text { SOFA score at ICU admission } \\
\text { in patients receiving NIV was } \\
\text { higher than in patients with } \\
\text { successful NIV }\end{array}$ \\
\hline 74 & Case control study & $\begin{array}{l}\text { Conventional invasive ventila- } \\
\text { tion } \\
\text { vs } \\
\text { Non-invasive ventilation }\end{array}$ & COVID-19 & 203 & $\begin{array}{l}\text { CPAP resulted in a lower risk } \\
\text { of death for patients admitted } \\
\text { within } 7 \text { days; }\end{array}$ \\
\hline
\end{tabular}

[67]. Main studies assessing steroids effects of patients with viral pneumonia are summarized in Table 2.

\section{Heparins}

Before the current COVID-19 pandemic, only a retrospective study on patients with ARDS after Influenza A (H1N1) supported the use of thromboprophylaxis with heparin in patients with viral pneumonia [68]. A retrospective study comparing patients with COVID-19 to those with Influenza A evaluated the effects of different thromboprophylaxis strategies on 152 patients admitted to 2 intensive care units. An association between high dose (200 UI x kg per day) dalteparin and reduction of mortality in respect to those receiving low or middle dose of heparin was reported (hazard ratio of death 0.33 ; 95\% confidence intervals $0.13-0.87$ ) [69, 70]. Although the majority of the studies report a favorable effect of anticoagulant therapy, no consensus exists about the timing and dosage of heparins in patients with COVID-19 [71].

\section{Non-invasive ventilation}

The ongoing COVID-19 pandemic has increased the need for the treatment of acute respiratory failures and the awareness of non-invasive ventilation (NIV), which gives the advantage of managing respiratory failure possibly avoiding endotracheal intubation.

An observational study evaluating patients with influenza A (H1N1) admitted in ICU established that an NIV was associated with a success rate of $40.6 \%$ and mortality comparable to that reported among patients intubated from the beginning of the respiratory failure. The success of NIV was predictable by fewer than 2 chest X-ray quadrant opacities and no vasopressor requirements by multivariate analysis. Another retrospective study investigating the efficacy of early NIV treatment for respiratory failure in patients with severe CAP identified 32 patients with NIV failure. The main factors associated with failure were comorbidities, high chest $\mathrm{X}$-ray score, high $\mathrm{LDH}$ and lack of $\mathrm{PaO}_{2} / \mathrm{FiO}_{2}$ improvement after one hour of ventilation. NIV complications were not severe and limited to skin lesions in many cases. A retrospective case-control retrospective study investigating the efficacy of different approaches to NIV in COVID-19 patients demonstrated an advantage after early (within 7 days from admission) continuous positive air pressure (CPAP) intervention. Instead, an increase in the risk of death was reported for patients receiving CPAP after 7 days from admission [72-75] (Tab. 3).

\section{Conclusions}

Viral pneumonia is an underestimated pathology with a relevant impact on elderly and immunocompromised patients. The most common etiologic agent of viral pneumonia in adults is rhinovirus. Influenza virus is frequently diagnosed, and several cases are reported among patients infected by Influenza A (H1N1) virus. Presenting signs of viral pneumonia are non-productive cough, dyspnea, fever, and pleuritic chest pain, but severe cases can report rapidly worsening respiratory failure. Drugs currently available have limited efficacy.

The current COVID-19 pandemic is increasing the awareness of viral pneumonia focusing the attention on previously under-investigated treatments and procedures such as steroids, immunosuppressive combination therapies, or NIV [60, 75]. Limited availability and efficacy of antivirals active against etiologic agents of viral pneumonia prompt 
the investigators to reposition drugs currently used for other viral etiologies, as already performed for other pathologies $[76,77]$. Present investigations have failed in demonstrating the efficacy of virtually all the antiviral drugs examined.

\section{Declarations}

Conflict of interest The authors declare no affiliations with or involvement in any organization or entity with any financial or nonfinancial interest related to this manuscript.

\section{References}

1. Ruuskanen O, Lahti E, Jennings LC, Murdoch DR. Viral pneumonia. Lancet. 2011;377:1264-75. https://doi.org/10.1016/S01406736(10)61459-6.

2. Brittain-Long R, Nord S, Olofsson S, Westin J, Anderson LM, Lindh M. Multiplex real-time PCR for detection of respiratory tract infections. J Clin Virol. 2008;41:53-6. https://doi.org/10. 1016/j.jcv.2007.10.029.

3. Bénézit F, Loubet P, Galtier F, et al. Non-influenza respiratory viruses in adult patients admitted with influenza-like illness: a 3-year prospective multicenter study. Infection. 2020;48:489-95. https://doi.org/10.1007/s15010-019-01388-1.

4. Almeida A, Boattini M, Christaki E, et al. Comparative virulence of seasonal viruses responsible for lower respiratory tract infections: a southern European multi-centre cohort study of hospital admissions. Infection. 2021. https://doi.org/10.1007/ s15010-020-01569-3.

5. Perlman S. Another decade, another coronavirus. N Engl J Med. 2020;382:760-2. https://doi.org/10.1056/NEJMe2001126.

6. Rodriguez-Morales AJ, Bonilla-Aldana DK, Balbin-Ramon GJ, Rabaan AA, Sah R, Paniz-Mondolfi A, Pagliano P, Esposito S. History is repeating itself: probable zoonotic spillover as the cause of the 2019 novel coronavirus epidemic. Infez Med. 2020;28:3-5.

7. Kelesidis T, Mastoris I, Metsini A, Tsiodras S. How to approach and treat viral infections in ICU patients. BMC Infect Dis. 2014;14:321. https://doi.org/10.1186/1471-2334-14-321.

8. Liu X, Cao W, Li T. High-dose intravenous immunoglobulins in the treatment of severe acute viral pneumonia: the known mechanisms and clinical effects. Front Immunol. 2020;11:1660. https:// doi.org/10.3389/fimmu.2020.01660.

9. Jain S. Epidemiology of viral pneumonia. Clin Chest Med. 2017;38:1-9. https://doi.org/10.1016/j.ccm.2016.11.012.

10. Jain S, Self WH, Wunderink R, et al. Community-acquired pneumonia requiring hospitalization among US adults. N Engl J Med. 2015;373:415-27.

11. Alimi Y, Lim WS, Lansbury L, Leonardi-Bee J, Nguyen-Van-Tam JS. Systematic review of respiratory viral pathogens identified in adults with community-acquired pneumonia in Europe. J Clin Virol. 2017;95:26-35. https://doi.org/10.1016/j.jcv.2017.07.019.

12. Topoulos S, Giesa C, Gatermann S, Fussen R, Lemmen S, Ewig $\mathrm{S}$. Analysis of acute respiratory infections due to influenza virus A, B and RSV during an influenza epidemic 2018. Infection. 2019;47:425-33. https://doi.org/10.1007/s15010-018-1262-x.

13. Gadsby NJ, Russell CD, McHugh MP, Mark H, Conway Morris A, Laurenson IF, Hill AT, Templeton KE. Comprehensive molecular testing for respiratory pathogens in community-acquired pneumonia. Clin Infect Dis. 2016;62:817-23. https://doi.org/10.1093/cid/ civ1214.

14. Albrich WC, Rassouli F, Waldeck F, Berger C, Baty F. Influence of older age and other risk factors on pneumonia hospitalization in Switzerland in the pneumococcal vaccine era. Front Med (Lausanne). 2019;6:286. https://doi.org/10.3389/fmed.2019.00286.

15. Kim YJ, Lee ES, Lee YS. High mortality from viral pneumonia in patients with cancer. Infect Dis (Lond). 2019;51:502-9. https:// doi.org/10.1080/23744235.2019.1592217.

16. Antinori S, Galimberti L, Milazzo L, Ridolfo AL. Bacterial and fungal infections among patients with SARS-CoV-2 pneumonia. Infez Med. 2020;28:29-36 (PMID: 32532935).

17. Cheng ZJ, Shan J. 2019 Novel coronavirus: where we are and what we know. Infection. 2020;48:155-63. https://doi.org/10. 1007/s15010-020-01401-y.

18. Salzberger B, Buder F, Lampl B, et al. Epidemiology of SARSCoV-2. Infection. 2020. https://doi.org/10.1007/s15010-02001531-3 (In press).

19. Dandachi D, Rodriguez-Barradas MC. Viral pneumonia: etiologies and treatment. J Investig Med. 2018;66:957-65. https://doi. org/10.1136/jim-2018-000712.

20. Gu X, Zhou F, Wang Y, Fan G, Cao B. Respiratory viral sepsis: epidemiology, pathophysiology, diagnosis and treatment. Eur Respir Rev. 2020;29:200038. https://doi.org/10.1183/16000617. 0038-2020 (PMID: 32699026).

21. Pagliano P, Spera AM, Ascione T, Esposito S. Infections causing stroke or stroke-like syndromes. Infection. 2020;48:323-32. https://doi.org/10.1007/s15010-020-01415-6.

22. Casalino E, Antoniol S, Fidouh N, et al. Influenza virus infections among patients attending emergency department according to main reason to presenting to ED: A 3-year prospective observational study during seasonal epidemic periods. PLoS ONE. 2017;12:e0182191. https://doi.org/10.1371/journal.pone.0182191.

23. Maruyama T, Fujisawa T, Suga S, et al. Outcomes and prognostic features of patients with influenza requiring hospitalization and receiving early antiviral therapy: a prospective multicenter cohort study. Chest. 2016;149:526-34.

24. Minney-Smith CA, Selvey LA, Levy A, Smith DW. Post-pandemic influenza $\mathrm{A} / \mathrm{H} 1 \mathrm{~N} 1 \mathrm{pdm} 09$ is associated with more severe outcomes than $\mathrm{A} / \mathrm{H} 3 \mathrm{~N} 2$ and other respiratory viruses in adult hospitalisations. Epidemiol Infect. 2019;147:e310. https://doi.org/10.1017/ S095026881900195X.

25. Liu WK, Liu Q, Chen DH, et al. Epidemiology and clinical presentation of the four human parainfluenza virus types. BMC Infect Dis. 2013;13:28. https://doi.org/10.1186/1471-2334-13-28.

26. Shah DP, Shah PK, Azzi JM, Chemaly RF. Parainfluenza virus infections in hematopoietic cell transplant recipients and hematologic malignancy patients: a systematic review. Cancer Lett. 2016;370:358-64. https://doi.org/10.1016/j.canlet.2015.11.014.

27. Walsh EE, Peterson DR, Falsey AR. Is clinical recognition of respiratory syncytial virus infection in hospitalized elderly and high-risk adults possible? J Infect Dis. 2007;195:1046-51. https:// doi.org/10.1086/511986.

28. Godefroy R, Giraud-Gatineau A, Jimeno MT, et al. Respiratory syncytial virus infection: Its propensity for bacterial coinfection and related mortality in elderly adults. Open Forum Infect Dis. 2020;7:546. https://doi.org/10.1093/ofid/ofaa546.

29. Loubet P, Lenzi N, Valette M, et al. Clinical characteristics and outcome of respiratory syncytial virus infection among adults hospitalized with influenza-like illness in France. Clin Microbiol Infect. 2017;23:253-9. https://doi.org/10.1016/j.cmi.2016.11.014.

30. Cao B, Huang GH, Pu ZH, et al. Emergence of communityacquired adenovirus type 55 as a cause of community-onset pneumonia. Chest. 2014;145:79-86. https://doi.org/10.1378/chest. 13-1186.

31. Gu J, Su QQ, Zuo TT, Chen YB. Adenovirus diseases: a systematic review and meta-analysis of 228 case reports. Infection. 2021;49:1-13. https://doi.org/10.1007/s15010-020-01484-7.

32. Park JY, Kim BJ, Lee EJ, et al. Clinical features and courses of adenovirus pneumonia in healthy young adults during an outbreak 
among korean military personnel. PLoS ONE. 2017;12:e0170592. https://doi.org/10.1371/journal.pone.0170592.

33. Choi SH, Huh JW, Hong SB, et al. Clinical characteristics and outcomes of severe rhinovirus-associated pneumonia identified by bronchoscopic bronchoalveolar lavage in adults: comparison with severe influenza virus-associated pneumonia. J Clin Virol. 2015;62:41-7. https://doi.org/10.1016/j.jcv.2014.11.010.

34. Kraft CS, Jacob JT, Sears MH, Burd EM, Caliendo AM, Lyon GM. Severity of human rhinovirus infection in immunocompromised adults is similar to that of $2009 \mathrm{H} 1 \mathrm{~N} 1$ influenza. J Clin Microbiol. 2012;50:1061-3. https://doi.org/10.1128/JCM. 06579-11.

35. Waqas QA, Abdullah HMA, Khan UI, Oliver T. Human cytomegalovirus pneumonia in an immunocompetent patient: a very uncommon but treatable condition. BMJ Case Rep. 2019;12:e230229. https://doi.org/10.1136/bcr-2019-230229.

36. Li L, Hsu SH, Gu X, et al. Aetiology and prognostic risk factors of mortality in patients with pneumonia receiving glucocorticoids alone or glucocorticoids and other immunosuppressants: a retrospective cohort study. BMJ Open. 2020;10:e037419. https://doi. org/10.1136/bmjopen-2020-037419.

37. Dong B, Wang Y, Wang G, Wang W, Zhou H, Fu Y. A retrospective study of cytomegalovirus pneumonia in renal transplant patients. Exp Ther Med. 2014;7:1111-5. https://doi.org/10.3892/ etm.2014.1577.

38. Iglesias L, Perera MM, Torres-Miñana L, Pena-López MJ. CMV viral load in bronchoalveolar lavage for diagnosis of pneumonia in allogeneic hematopoietic stem cell transplantation. Bone Marrow Transplant. 2017;52:895-7. https://doi.org/10.1038/bmt.2017.11.

39. Mirouse A, Vignon $P$, Piron $P$, et al. Severe varicella-zoster virus pneumonia: a multicenter cohort study. Crit Care. 2017;21:137. https://doi.org/10.1186/s13054-017-1731-0.

40. Scheithauer S, Manemann AK, Krüger S, et al. Impact of herpes simplex virus detection in respiratory specimens of patients with suspected viral pneumonia. Infection. 2010;38:401-5. https://doi. org/10.1007/s 15010-010-0036-x.

41. Luzzati R, D’Agaro P, Busca A, et al. Herpes simplex virus (HSV) pneumonia in the non-ventilated immunocompromised host: Burden and predictors. J Infect. 2019;78:127-33. https://doi.org/10. 1016/j.jinf.2018.09.010.

42. Mann R, Perisetti A, Gajendran M, Gandhi Z, Umapathy C, Goyal H. Clinical characteristics, diagnosis, and treatment of major coronavirus outbreaks. Front Med (Lausanne). 2020;7:581521. https:// doi.org/10.3389/fmed.2020.581521.

43. Brouwer MC, Ascione T, Pagliano P. Neurologic aspects of covid19: a concise review. Infez Med. 2020;28:42-5.

44. Elabbadi A, Turpin M, Gerotziafas GT, Teulier M, Voiriot G, Fartoukh M. Bacterial coinfection in critically ill COVID-19 patients with severe pneumonia. Infection. 2021. https://doi.org/10.1007/ $\mathrm{s} 15010-020-01553-\mathrm{x}$ (in press).

45. Du W, Yu J, Wang H, Zhang X, Zhang S, Li Q, Zhang Z. Clinical characteristics of COVID-19 in children compared with adults in Shandong Province. China Infect. 2020;48:445-52. https://doi. org/10.1007/s15010-020-01427-2.

46. Fumagalli A, Misuraca C, Bianchi A, et al. Pulmonary function in patients surviving to COVID-19 pneumonia. Infection. 2021;49:153-7. https://doi.org/10.1007/s15010-020-01474-9.

47. Moscona A. Neuraminidase inhibitors for influenza. N Engl J Med. 2005;353:1363-73. https://doi.org/10.1056/NEJMra050740.

48. Kaiser L, Wat C, Mills T, Mahoney P, Ward P, Hayden F. Impact of oseltamivir treatment on influenza-related lower respiratory tract complications and hospitalizations. Ann Intern Med. 2003;163:1667-72.

49. Shobugawa Y, Saito R, Sato I, Kawashima T, Dapat C, Dapat IC, et al. Clinical effectiveness of neuraminidase inhibitors-oseltamivir, zanamivir, laninamivir, and peramivir-for treatment of influenza $\mathrm{A}(\mathrm{H} 3 \mathrm{~N} 2)$ and $\mathrm{A}(\mathrm{H} 1 \mathrm{~N} 1)$ pdm09 infection: an observational study in the 2010-2011 influenza season in Japan. J Infect Chemother. 2012;18:858-64.

50. Wang K, Shun-Shin M, Gill P, Perera R, Harnden A. Neuraminidase inhibitors for preventing and treating influenza in children (published trials only). Cochrane Database Syst Rev. 2012;4:Cd002744.

51. Muthuri SG, Venkatesan S, Myles PR, et al. Impact of neuraminidase inhibitors on influenza $\mathrm{A}(\mathrm{H} 1 \mathrm{~N} 1)$ pdm09-related pneumonia: an individual participant data meta-analysis. Influenza Other Respir Viruses. 2016;10:192-204. https://doi.org/10. 1111/irv.12363.

52. Jefferson T, Demicheli V, di Pietrantonj C, Rivetti D. Amantadine and rimantadine for influenza $\mathrm{A}$ in adults. Cochrane Database Syst Rev. 2006;2:Cd00169.

53. Simões EAF, Bont L, Manzoni P, et al. Past, present and future approaches to the prevention and treatment of respiratory syncytial virus infection in children. Infect Dis Ther. 2018;7:87-120. https://doi.org/10.1007/s40121-018-0188-z.

54. Dominguez KD, Mercier RC. Treatment of RSV pneumonia in adults-evidence of ribavirin effectiveness? Ann Pharmacother. 1999;33:739-41. https://doi.org/10.1345/aph.18243.

55. Singh N, Winston DJ, Razonable RR, Lyon GM, Silveira FP, Wagener MM, Limaye AP. Cost effectiveness of preemptive therapy versus prophylaxis in a randomized clinical trial for the prevention of CMV disease in seronegative liver transplant recipients with seropositive donors. Clin Infect Dis. 2020. https://doi.org/10.1093/cid/ciaa1051.

56. Acosta E, Bowlin T, Brooks J, et al. Advances in the development of therapeutics for Cytomegalovirus infections. J Infect Dis. 2020;221:S32-44. https://doi.org/10.1093/infdis/jiz493.

57. Erard V, Guthrie KA, Seo S, et al. Reduced mortality of Cytomegalovirus pneumonia after hematopoietic cell transplantation due to antiviral therapy and changes in transplantation practices. Clin Infect Dis. 2015;61:31-9. https://doi.org/10.1093/ cid/civ215.

58. Papazian L, Doddoli C, Chetaille B, et al. A contributive result of open-lung biopsy improves survival in acute respiratory distress syndrome patients. Crit Care Med. 2007;35:755-62. https://doi. org/10.1097/01.CCM.0000257325.88144.30.

59. To KKW, Yip CCY, Yuen KY. Rhinovirus-from bench to bedside. J Formos Med Assoc. 2017;11:496-504. https://doi.org/10. 1016/j.jfma.2017.04.009.

60. Esposito S, Noviello S, Pagliano P. Update on treatment of COVID-19: ongoing studies between promising and disappointing results. Infez Med. 2020;28:198-211.

61. Pagliano P, Scarpati G, Sellitto C, Conti V, Spera AM, Ascione T, Piazza O, Filippelli A. Experimental pharmacotherapy for COVID-19: the latest advances. J Exper Pharmacol. 2021;13:1-13.

62. Durante-Mangoni E, Andini R, Bertolino L, Mele F, Florio LL, Murino P, Corcione A, Zampino R. Early experience with remdesivir in SARS-CoV-2 pneumonia. Infection. 2020;48:779-82. https://doi.org/10.1007/s15010-020-01448-x.

63. Yang JW, Fan LC, Miao XY, Mao B, Li MH, Lu HW, Liang $\mathrm{S}, \mathrm{Xu}$ JF. Corticosteroids for the treatment of human infection with influenza virus: a systematic review and meta-analysis. Clin Microbiol Infect. 2015;21:956-63. https://doi.org/10.1016/j.cmi. 2015.06.022.

64. Tsai MJ, Yang KY, Chan MC, et al. Impact of corticosteroid treatment on clinical outcomes of influenza-associated ARDS: a nationwide multicenter study. Ann Intensive Care. 2020;10:26. https://doi.org/10.1186/s13613-020-0642-4.

65. Li H, Yang SG, Gu L, et al. Effect of low-to-moderate-dose corticosteroids on mortality of hospitalized adolescents and adults with influenza A(H1N1)pdm09 viral pneumonia. Influenza Other 
Respir Viruses. 2017;11:345-54. https://doi.org/10.1111/irv. 12456.

66. Recovery Collaborative Group, et al. Dexamethasone in hospitalized patients with Covid-19-preliminary report. N Engl J Med. 2020. https://doi.org/10.1056/NEJMoa2021436.

67. WHO Rapid Evidence Appraisal for COVID-19 Therapies (REACT) Working Group. Association between administration of systemic corticosteroids and mortality among critically ill patients with COVID-19: a meta-analysis. JAMA. 2020;324:1330-41. https://doi.org/10.1001/jama.2020.17023.

68. Obi AT, Tignanelli CJ, Jacobs BN, Arya S, Park PK, Wakefield TW, Henke PK, Napolitano LM. Empirical systemic anticoagulation is associated with decreased venous thromboembolism in critically ill influenza A H1N1 acute respiratory distress syndrome patients. J Vasc Surg Venous Lymphat Disord. 2019;7:317-24. https://doi.org/10.1016/j.jvsv.2018.08.010.

69. Jonmarker S, Hollenberg J, Dahlberg M, et al. Dosing of thromboprophylaxis and mortality in critically ill COVID-19 patients. Crit Care. 2020;24:653. https://doi.org/10.1186/s13054-020-03375-7.

70. Piazza O. Should 1CU COVID-19 patients empirically receive therapeutic doses of anticoagulant? Infez Med. 2020;28:4-5.

71. Kollias A, Kyriakoulis KG, Syrigos NK, Stergiou GS. Anticoagulation therapy in COVID-19: is there a dose-dependent benefit? Thromb Res. 2020;199:19-20. https://doi.org/10.1016/j.thromres. 2020.12.013.

72. Masclans JR, Pérez M, Almirall J, Lorente L, Marqués A, Socias L, Vidaur L, Rello J, H1N1 GTEI/SEMICYUC Investigators.
Early non-invasive ventilation treatment for severe influenza pneumonia. Clin Microbiol Infect. 2013;19:249-56. https://doi. org/10.1111/j.1469-0691.2012.03797.x.

73. Nicolini A, Ferraioli G, Ferrari-Bravo M, Barlascini C, Santo M, Ferrera L. Early non-invasive ventilation treatment for respiratory failure due to severe community-acquired pneumonia. Clin Respir J. 2016;10:98-103. https://doi.org/10.1111/crj.12184.

74. Rello J, Rodríguez A, Ibañez P, et al. Intensive care adult patients with severe respiratory failure caused by Influenza A $(\mathrm{H} 1 \mathrm{~N} 1) \mathrm{v}$ in Spain. Crit Care. 2009;13:R148. https://doi.org/10.1186/cc8044.

75. Ashish A, Unsworth A, Martindale J, Sundar R, Kavuri K, Sedda L, Farrier M. CPAP management of COVID-19 respiratory failure: a first quantitative analysis from an inpatient service evaluation. BMJ Open Respir Res. 2020;7:e000692. https://doi.org/10. 1136/bmjresp-2020-000692.

76. Giudice V, Pagliano P, Vatrella A, et al. Combination of ruxolitinib and eculizumab for treatment of severe SARS-CoV-2-related acute respiratory distress syndrome: a controlled study. Front Pharmacol. 2020;11:857. https://doi.org/10.3389/fphar.2020. 00857.

77. Esposito V, Verdina A, Manente L, et al. Amprenavir inhibits the migration in human hepatocarcinoma cell and the growth of xenografts. J Cell Physiol. 2013;228:640-5. https://doi.org/10. 1002/jcp. 24173. 